\title{
Egg-guarding behavior of the treehopper Ennya chrysura (Hemiptera: Membracidae): female aggregations, egg parasitism, and a possible substrate-borne alarm signal
}

\author{
Ximena Miranda \\ Escuela de Biología, Universidad de Costa Rica, Ciudad Universitaria Rodrigo Facio, 2060 San José, Costa Rica; \\ ximena.miranda@ucr.ac.cr
}

Received 03-VI-2015. C Corrected 09-II-2016. Accepted 09-III-2016.

\begin{abstract}
Treehoppers are known for their substrate-borne communication and some of them also for their subsocial behavior. Following a more general study of the natural history and substrate-borne signal repertoire of the treehopper Ennya chrysura, the objective of this paper was to explore in greater depth the signals and other behaviors associated specifically to egg-guarding. Theese were studied both in natural and laboratory conditions between July, 2000 and March, 2004. The spatial distribution of egg guarding females was studied in the natural population; recording equipment and playback experiments were used in the laboratory and then analyzed digitally. Under natural conditions (San Antonio de Escazú, Costa Rica), female E. chrysura guard their egg masses and egg-guarding was associated with lower parasitism of the eggs from the wasps Gonatocerus anomocerus and Schizophragma sp. (Mymaridae). Females tended to place their eggs close to other egg-guarding females and they produced substrate-borne vibrations when disturbed. An aggregated pattern under natural conditions was confirmed by calculating dispersion indices from egg-clutch data obtained from 66 leaves in the field. The disturbance signal was characterized from laboratory recordings of substrate-borne vibrations of 10 egg-guarding females. Experiments conducted in the laboratory with 18 egg-guarding females showed that those which were previously exposed to the disturbance signal of another female moved slightly or vibrated more during playbacks and that they reacted more quickly and exhibited more deffensive behaviors in response to a tactile stimulus. The signals produced while defending against egg parasites may therefore function as an alarm and favor aggregating behavior of egg-guarding females. Rev. Biol. Trop. 64 (3): 1209-1222. Epub 2016 September 01.
\end{abstract}

Key words: treehopper communication, mutualistic brood care, insect behavior, Ennya chrysura.

In the introduction to his beautiful study of periodical cicadas (Magicicada spp.), Marshall (2000) wrote that "the brilliant may occasionally manage to anticipate significant discoveries while wading through the confusion of published information, to guess correctly when and where to look and what to measure, but for the rest of us the best investment is simply time spent in the field testing the best questions we have at the moment, watching and listening to the organisms, and waiting for the surprises." It was in this spirit that I started studying the treehopper Ennya chrysura (Fairmaire, 1846; Membracidae, Smiliinae, Polyglyptini) and the surprises have been many.
Signal duets for mate localization, female and male advertisement calls, signals associated with male-male interactions and disturbance signals occur in this species (Godoy, Miranda, \& Nishida, 2006; Miranda, 2006), as in other treehoppers (Cocroft, 2003; Cocroft \& Rodríguez, 2005; Cocroft \& McNett, 2006; Morales, Barone, \& Henry, 2008). The repertoire of adult E. chrysura includes eight different signals (Miranda, 2006), more than any other membracid species in which plantborne communication has been studied (Cocroft, 2003; Cocroft \& Rodríguez, 2005; Cocroft \& McNett, 2006). Treehopper male jamming of other males' courtship song was documented for the first 
time in E. chrysura (Miranda, 2006). The present study documents another possible new way in which plantborne vibrations are used in $E$. chrysura: mutualistic brood care.

Parental care is widespread in insects, occurring in at least 47 families of 13 orders, and treehoppers provide some of the best examples (Lin, 2006; Wong, Meunier, \& Kölliker, 2013). Females of various membracid species remain on top of their egg masses after oviposition, using their bodies as a physical shield and exhibiting aggressive behaviors to protect eggs against predators or parasitoids (Godoy et al., 2006; Lin, 2006; Camacho, Keil, \& Dangles, 2014). Cooperative brood care by females, as in subsocial hymenopterans, Blattodea, Passalidae (Coleoptera) and Thysanoptera has not been documented in treehoppers (Lin, 2006; Wong et al., 2013), but brood mutualism (also called "egg dumping" because a female inserts her eggs on another female's clutch) occurs in Polyglypta dispar (Eberhard, 1986). In many other species two or more females often oviposit in close proximity of each other (Wood, 1984; Stegmann \& Linsenmair, 2002; Godoy et al., 2006; Camacho et al., 2014). The possible advantages of this behavior include increasing the group size of feeding nymphs to attract ants, creating a nutrient sink in the plant, and mutual defense against predators or parasitoids (Lin, 2006). Female aggregation may also reduce the risk of egg parasitism because of the dilution of the probabilities of being found or being attacked (Camacho et al., 2014). Here I propose and test that, in E. chrysura, vibrations produced by nearby egg - guarding females as a response to predators and parasitoids, may provide a mutualistic advantage that favors oviposition in close proximity to other guarding females.

Females of E. chrysura can insert 2-6 eggs per day into a leaf vein, forming clutches of up to 80 eggs that they can either guard or abandon (Godoy et al., 2006). When an E. chrysura female is guarding her eggs, attacks by predators or parasitoids on the female or on her eggs release defensive behavior, which includes production of substrate-borne vibrations (Godoy et al., 2006). Signals of this kind are known as disturbance, defense, or alarm signals, and are thought to function in repelling predators or warning them that further defenses are forthcoming (Masters, 1979; Buchler, Wright, \& Brown, 1981; Klump \& Shalter, 1984; Claridge, 1985; Cocroft \& Hamel, 2010). Guarding eggs near another female may be advantageous because this signal from other defending females could function as an alarm. A similar function was suggested for disturbance signals produced by guarding females of the treehopper Publilia concava (Cocroft \& Hamel, 2010) and Alchisme grossa (Camacho et al., 2014), but experiments have not been conducted to test this. In this study I demonstrate experimentally that disturbance signals by nearby guarding females increase the likelihood of active egg defense by female E. chrysura.

\section{MATERIAL AND METHODS}

Establishment of the colony: I initiated a colony of Ennya chrysura at a house garden in Sabanilla de Montes de Oca, San José, Costa Rica (1 300 m elevation). Approximately 200 individuals were randomly collected on their host plant, Solanum betaceum (Solanaceae), in an abandoned coffee plantation at San Antonio de Escazú, San José, Costa Rica (1 400 m elevation) on 16 - XI - 2000 (Miranda, 2006). For the experimental procedure of the present study, mature females that had already copulated were drawn from the colony to be kept separately (one female per plant) on small individuals of their host plant $(0.5-1 \mathrm{~m}$ high), grown in plastic pots from cuttings. Females were marked on one side of the pronotum. A small piece of transparent acetate film with a number printed on it with a laser printer (Arial font, size 4) was glued to the pronotum with a small drop of Testors Gloss Enamel paint.

Egg parasitism: In the population under natural conditions (San Antonio de Escazú), 13 leaves with an unguarded clutch and 16 with a guarding female on a clutch were covered with a nylon mesh bag. Mean clutch size was $48 \pm$ 
26 eggs $(\mathrm{N}=29)$ and no more than three clutches were selected from an individual tree. It was not possible to determine if unguarded clutches were abandoned by the female or if the female was killed by natural enemies or dislodged by wind or rain. The leaf stem was covered with a foam band below the bag, and the bag was tied over the foam, so that parasitoids emerging from eggs could not escape. Since females would have continued laying eggs (under protection from parasitoids), before covering the leaves, the females were removed. This was done to avoid underestimation of parasitism. Covered leaves were collected two or three weeks later, and were placed in a ventilated room; water was sprayed onto clutches in order to prevent un-hatched eggs from desiccating. This whole procedure was done to promote normal development of nymphs and parasitoids, and therefore obtain a better estimation of parasitism percentages.

Adult parasitoid wasps were collected and sent to John Huber (Canadian National Collection), who confirmed the identification of two Mymaridae species: Schizophragma sp. and Gonatocerus anomocerus (Crawford, 1913). The wasps that did not complete their development were assumed to be one of the previous species, because no other egg parasitoids had been identified so far in eggs of E. chrysura, and because of the characters described below. Parasitoid wasps that did not complete their development were extracted from un-hatched eggs and observed under a dissecting microscope. Schizophragma sp. was distinguished by its slender body, thin antennae, and four tarsomeres. G. anomocerus was more robust, had a reddish pigmentation on its legs and antennae, and five tarsomeres. The opening of an egg was circular when a wasp had emerged, and linear when a nymph emerged; this fact was also used to calculate parasitism percentages.

\section{Spatial distribution of egg-guarding} females: In the field, the numbers of clutches per leaf were counted in $S$. betaceum trees that had at least four egg masses. If the tree was less than $1.5 \mathrm{~m}$ high, all the leaves were used; these trees were saplings which had a main stem bearing leaves. If the tree was more than 1.5 $\mathrm{m}$ high, two accessible branches with at least 25 leaves were chosen. The index of dispersion (Krebs, 1999) was calculated using each leaf as a sample unit. When there were at least two females guarding eggs on a leaf (Fig. 1A), I measured the linear distance between each female and her closest neighbor for 38 pairs. In 66 leaves, old clutches could be distinguished from new ones. An old clutch had dry or empty eggs, while a new one either had a guarding female and/or had shiny eggs lacking emergence holes. The dispersion index was calculated for each clutch category (old and new).

Size and age of leaves could affect female distribution, so I considered these in five trees.
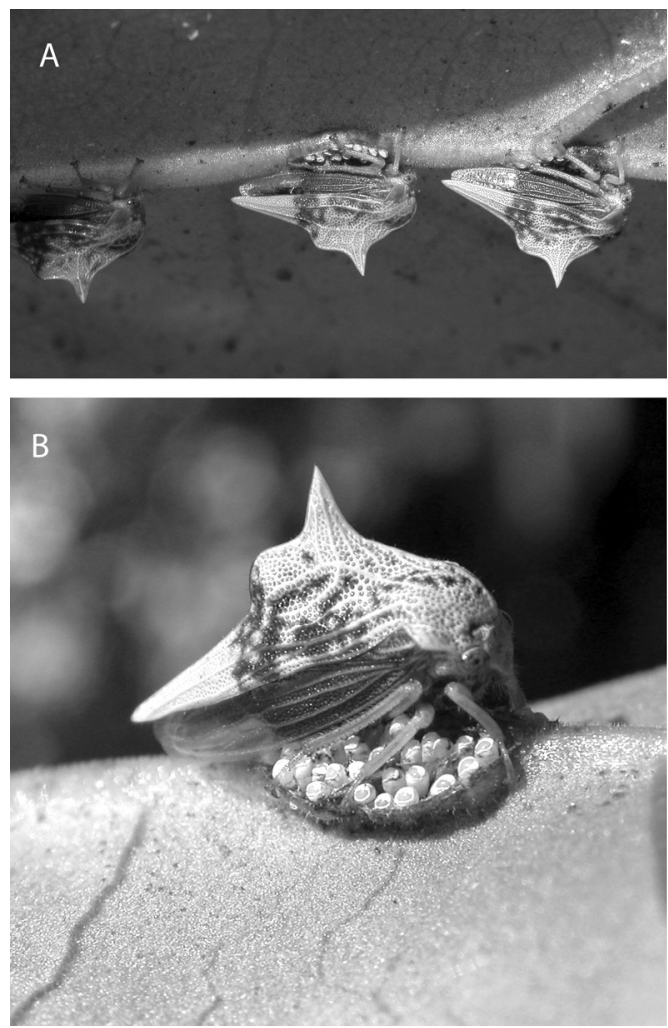

Fig. 1. A) Two females of Ennya chrysura (on the right side) guarding their eggs in close proximity to each other. B) A female of Ennya chrysura guarding her egg mass in the underside of a leaf; the leaf was turned upside down to facilitate view (Images by Kenji Nishida). Sabanilla de Montes de Oca, Costa Rica. 
Leaf length (distance between base and apex) and width (maximum width of the leaf) were measured with a metric tape to the closest $\mathrm{mm}$. The preference for leaves of certain size was evaluated with a homogeneity chi-square test.

The relative ages of leaves were determined by numbering them from top to bottom, with lower numbers corresponding to younger leaves. A test for correlation was calculated for leaf age-number and clutches per leaf, and this was evaluated with a chi-square test for homogeneity. A similar test that considered the presence of at least one clutch in relation to leaf age-number was used to evaluate the preference for leaves of certain age.

Recording and playback equipment: Substrate-borne vibrations and video were recorded with a phonograph cartridge (Model 91T, Astatic, Solon, $\mathrm{OH}$ ) and a custom-made amplifier, connected to a digital video camera (Model PV - DV400D, Panasonic, Secaucus, NJ). Playbacks utilized a modified Mini Speaker $29 \mathrm{~mm}$ in diameter and 8 Ohm (Model 273 - 092, Radio Shack, Fort Worth, TX) with a small balsa wood stick ( 2 × 2 mm thick, $1 \mathrm{~cm}$ long) glued perpendicular to the center of the membrane. The rest of the membrane (except for a thin band covering the copper voice coil of the speaker) was carefully cut away with a scalpel to reduce the production of airborne vibrations. The tip of the stick was placed in contact with the stem or central vein of a leaf. The speaker was connected to the audio output of a portable computer (Sound card MagicMedia 256AV, NeoMagic, San Jose, CA).

Signal description: Ten egg-guarding females were brought into the laboratory, each on its own plant and one at a time (Fig. 1B). The egg-guarding females were disturbed by touching their legs with a paintbrush until they produced disturbance vibrations. The signals were recorded by the phonograph cartridge placed $10 \mathrm{~cm}$ from the female. Signals were digitized at $22 \mathrm{kHz}$ with 16-bit resolution and analyzed with Cool Edit Pro 1.2 (Syntrillium Software Corporation, 1999). Pulses were counted on a spectrogram with $64 \mathrm{~ms}$ time resolution. Only clear vertical bands between 1500 and $4000 \mathrm{~Hz}$ that spanned at least $0.2 \mathrm{~s}$ segments on the computer screen were counted. The signals were compared with previous recordings of drumming, a disturbance signal that was previously observed in non-guarding females as part of the 8 signal repertoire of this species (Miranda, 2006). This was done in order to determine if egg-guarding females were producing a different disturbance signal. T-tests or Mann Whitney U tests (Zar, 1996) were used according to the need of parametrical or non-parametrical analyses.

Playback stimulus calibration: Before the experiments, I calibrated the intensity of the playbacks so that it was similar to the signals produced by females. An egg-guarding female, which was alone on a plant, was taken into the laboratory. The phonograph cartridge was placed $15 \mathrm{~cm}$ away from the female, and her legs were touched with a paintbrush until she emitted the disturbance signal. Vibrations were recorded with the portable computer at 22 $\mathrm{kHz}$ with 16-bit resolution, using Saslab Pro 4.15 software (Avisoft Bioacoustics, 2002). The intensity of the signal received with the phonograph cartridge was registered with Cool Edit Pro 1.2 software (Syntrillium Software Corporation, 1999). After the female vibrated, she was removed and the balsa wood stick was placed where the female had been. The signal of another female (Fig. 2A) was then played back at different volumes; level 3 produced an intensity that was slightly lower than the signal of the live female (a difference of $-1.53 \mathrm{~dB}$ ). Therefore, the volume was set at level 3 during playback experiments to prevent the signal from being similar to another kind of disturbance. Mean intensity $(\mathrm{dB})$ was determined with Cool Edit Pro 1.2 software (Syntrillium Software Corporation 1999); this was done in at least two segments of the signal produced by a female and two segments of the playback through the same plant. Spectrograms of the last segment of the signal and the same segment after it traveled through separate plants 
A

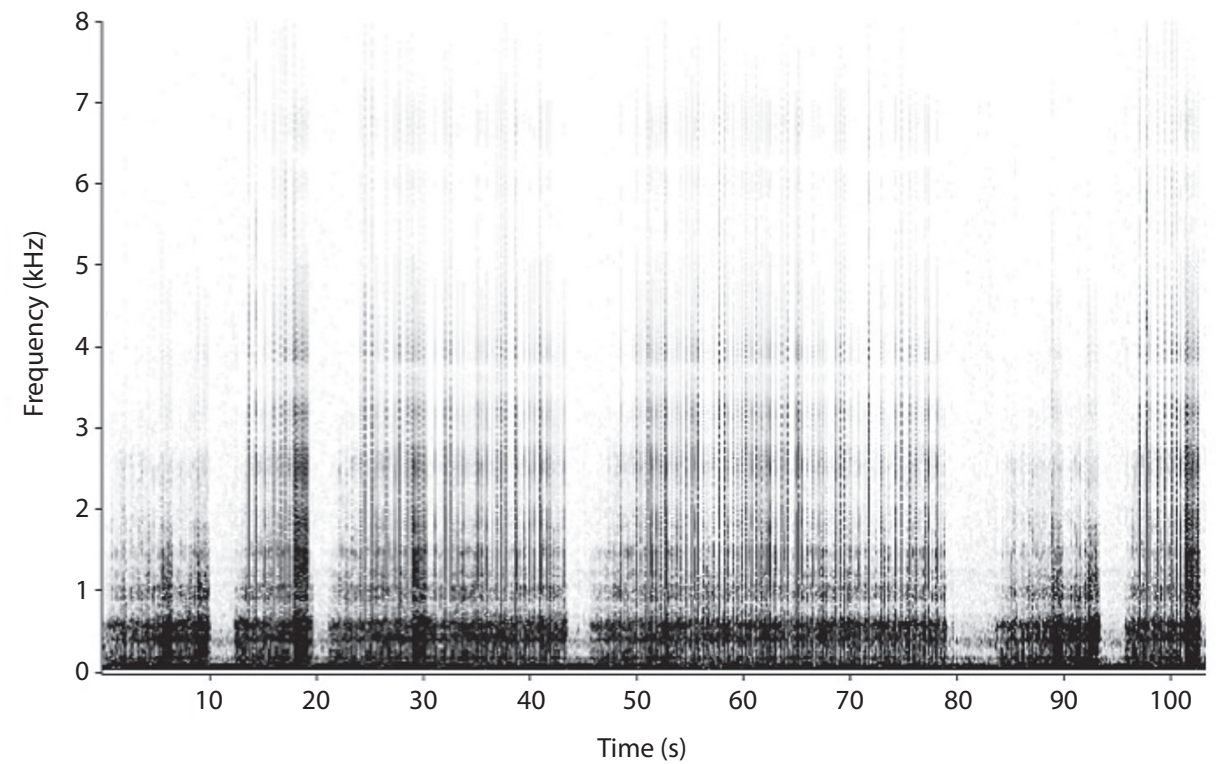

B
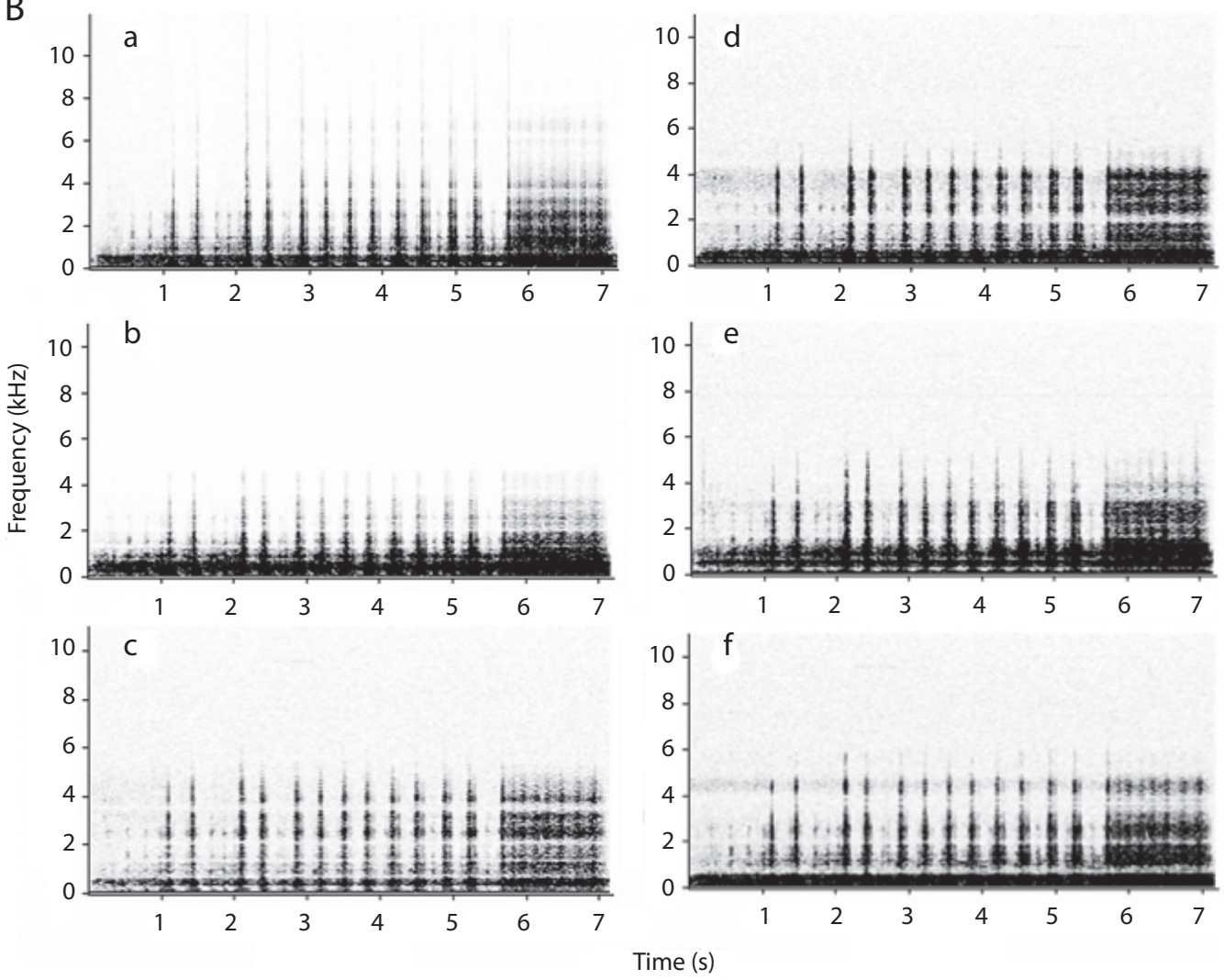

Fig. 2. A) Spectrogram of the E. chrysura disturbance signal used as a stimulus in playback experiments. B) Spectrograms of the final segment of the previous signal used in playback experiments (a) and of the same segment after traveling through five different plants (b-f). 
are shown, to demonstrate the quality of the playback system and signal consistency across plants (Fig. 2B). Mean temperature during these recordings was $25.6 \pm 1.0^{\circ} \mathrm{C}$.

Experimental design: Ten egg-guarding females were brought into the laboratory, each on its own plant and one at a time, at least 12 hours before the experiments started. If the females' disturbance signal is utilized by other females as an alarm, a female will respond more quickly and intensely to a given stimulus after being exposed to the disturbance signal of a neighboring female. To test this hypothesis, each plant with a female whose guarded clutch had at least 30 eggs and was visible lateral to the female (Fig. 1B) was carefully placed in the laboratory. The balsa stick of the modified speaker was placed perpendicular to the leaf, $3 \mathrm{~cm}$ behind the female, on the same stem or central vein where the eggs were inserted and guarded by the female, but over the leaf (female was under the leaf). The phonograph cartridge was placed on the main stem of the plant, $10-15 \mathrm{~cm}$ away from the female and then the following experimental cycle was carried out. Behaviors were taped and substrate borne vibrations were recorded during the whole experimental procedure, starting with 3 min. of recording basal behavior. Experimental females were exposed to a playback of another female's disturbance signal (Fig. 2A) after these $3 \mathrm{~min}$. Immediately after the playback finished, the female was touched once with a brush made with five hairs ( $1 \mathrm{~cm}$ long) attached to the end of a transparent straw. The legs of the female were touched on the side on which the camera was focused, moving from behind the female so that she could not see the brush coming. This tactile stimulus was administered by a person who was not aware of either the predictions or the objectives of the experiment and she tried to do it with the same strength. Recordings were stopped $3 \mathrm{~min}$. after the stimulus. For the control females, the speaker was silent instead of producing the playback of another female but the rest of the procedure was identical. The order of tests (control, experimental) was alternated for successive females.

This experiment was repeated with 18 females, all of them with the same playback (Fig. 2A), waiting $30 \mathrm{~min}$. between tests. If after these $30 \mathrm{~min}$. the female still emitted vibrations, I waited another $30 \mathrm{~min}$. until she was silent (this was only necessary once or twice). For 13 of those females, a second repetition was performed at least one day later. Temperature was measured $2 \mathrm{~min}$. before each control and treatment test; the mean was 24.1 $\pm 1.9^{\circ} \mathrm{C}$ ( \pm S.D., $\mathrm{N}=86$, range $\left.20-28{ }^{\circ} \mathrm{C}\right)$. All experiments were done between 29 - IV - 2002 and 29 - X - 2002.

Female behavior analysis: The frequencies with which female behaviors occurred were quantified with J Watcher 0.9 software (Blumstein, Evans, \& Daniel, 2000). A "slight movement" was any lateral or upward movement of the body or sliding of the legs against the plant. A "kick" consisted of raising one or both hind legs until it was almost perpendicular to the leaf or stem, followed by a strong hit against the plant. A "vibration" was a period during which a female produced uninterrupted substrate-borne vibrations for more than $2 \mathrm{~s}$. The sum of observed frequencies of these three kinds of behaviors was the "total reaction".

I measured the "reaction time" (in seconds), defined as the time between contact with the brush and the first reaction of the female (any of the three behaviors defined above), with a Mini-DV player and a TV. When the brush contacted the female, the slight movement with which she regained her original position was not considered the first reaction. When the female did not react during the $3 \mathrm{~min}$. period after the tactile stimulus, the reported reaction time was $180 \mathrm{~s}$. Means were given \pm 1 standard deviation and statistical tests were two-tailed unless indicated. Wilcoxon paired-sample tests (Zar, 1996) were used to compare these response variables between experimental and control females. Statistical analyses of the first and second repetitions 
performed a day or later were done separately to avoid pseudoreplication.

\section{RESULTS}

Egg parasitism: Clutches with guarding females were parasitized less than undefended clutches (t-test $=7.26$, d.f. $=27, \mathrm{P}<0.001$ ); mean parasitism was $26.0 \pm 15.8 \%(\mathrm{~N}=13)$ in guarded egg masses and $79.6 \pm 15.8 \%(\mathrm{~N}=16)$ in unguarded ones. Four unguarded clutches were parasitized only by Schizophragma sp., three only by G. anomocerus, and four by both species (in two clutches the wasp species could not be distinguished). Two guarded clutches were not parasitized, eight were only parasitized by G. anomocerus, none only by Schizophragma sp., and one by both species (in five clutches the wasp species could not be distinguished).

Signal description: The vibration produced after a tactile stimulus (i.e. disturbance signal) consisted of pulse trains that had a mean of 29.6 \pm 15.1 pulses per second $(\mathrm{N}=10)$, and was very similar to the drumming signal $(27.6$ \pm 13.4 pulses per second, $\mathrm{N}=6$; $\mathrm{t}$-test $=0.26$, d.f. $=14, \mathrm{P}=0.80$; Fig. 3 ) that was previously described for this species (Miranda, 2006). The mean duration of train pulses was $4.3 \pm 6.2 \mathrm{~s}$ $(\mathrm{N}=9)$ and again there was no significant difference with drumming as reported by Miranda
(2006) $(1.7 \pm 0.9 \mathrm{~s})$ [Mann Whitney U-test= $30.5, \mathrm{~N}_{1}=6$ (drumming) and $\mathrm{N}_{2}=9$ (disturbance signal), $\mathrm{P}=0.68]$. The mean duration of silent intervals between pulse trains was $5.8 \pm$ $7.8 \mathrm{~s}(\mathrm{~N}=9)$ and was significantly greater than drumming intervals previously described $(0.7$ $\pm 1.1 \mathrm{~s}$ ) [Mann Whitney U-test $=44.5, \mathrm{~N}_{1}=6$ (drumming) and $\mathrm{N}_{2}=9$ (disturbance signal), $\mathrm{P}=0.04]$. The mean duration of train pulses to interval duration in disturbance vibrations was $2.2 \pm 2.1(\mathrm{~N}=9)$ and was significantly lower than in the drumming signal $(7.5 \pm 5.6)$ [Mann Whitney U- test $=9.5, \mathrm{~N}_{1}=6$ (drumming) and $\mathrm{N}_{2}=9$ (disturbance signal), $\mathrm{P}=0.04$ ]. Relatively long segments $(1.8 \pm 0.7 \mathrm{~s})$ of 80 or more pulses per second (Fig. 4) never occurred in drumming, but occurred in $50 \%(\mathrm{~N}=10)$ of the females stimulated with the brush.

Spatial distribution of egg-guarding females: Egg clutches were highly aggregated on the leaves, with a dispersion index of 2.96 considering both old and new clutches (greater than random, chi square test: $x^{2}=431.86$, d.f. $=$ $146, \mathrm{P}<0.001$; Fig. 5). Five trees showed significant aggregated indices when this index was calculated separately for each tree (Table 1). The mean distance between pairs of neighboring egg-guarding females was $2.8 \pm 2.5 \mathrm{~cm}$ $(\mathrm{N}=38$; range $1-100 \mathrm{~mm})$. The dispersion indices of old clutches (3.75) and new clutches

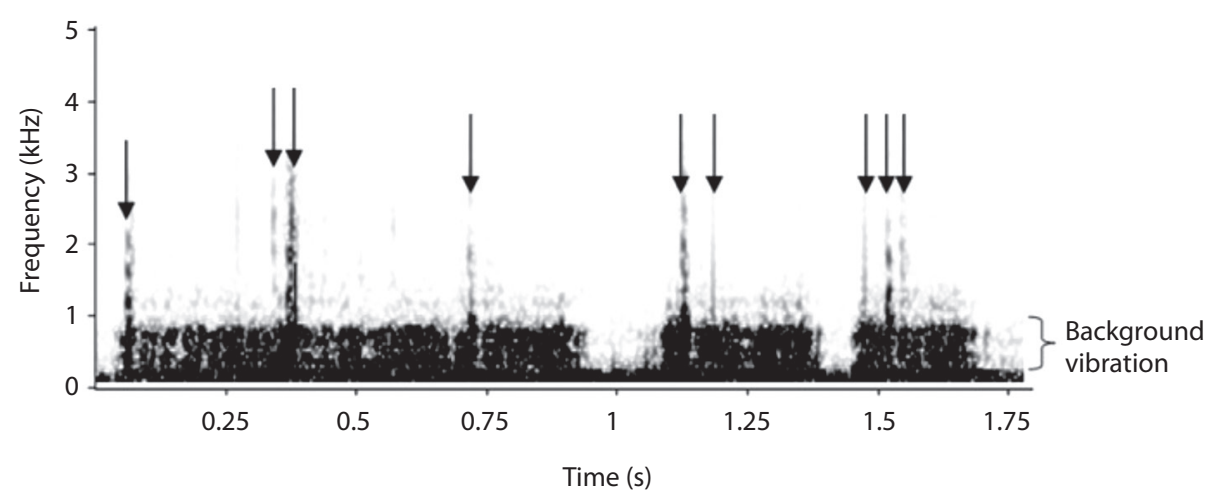

Fig. 3. Spectrogram of a segment of the disturbance signal of an E. chrysura female. Three pulse trains are separated by silent intervals; vertical bands represent the signal's pulses (indicated with arrows), and a background signal band from 0 to $800 \mathrm{~Hz}$ approximately can be seen in the figure where indicated. 

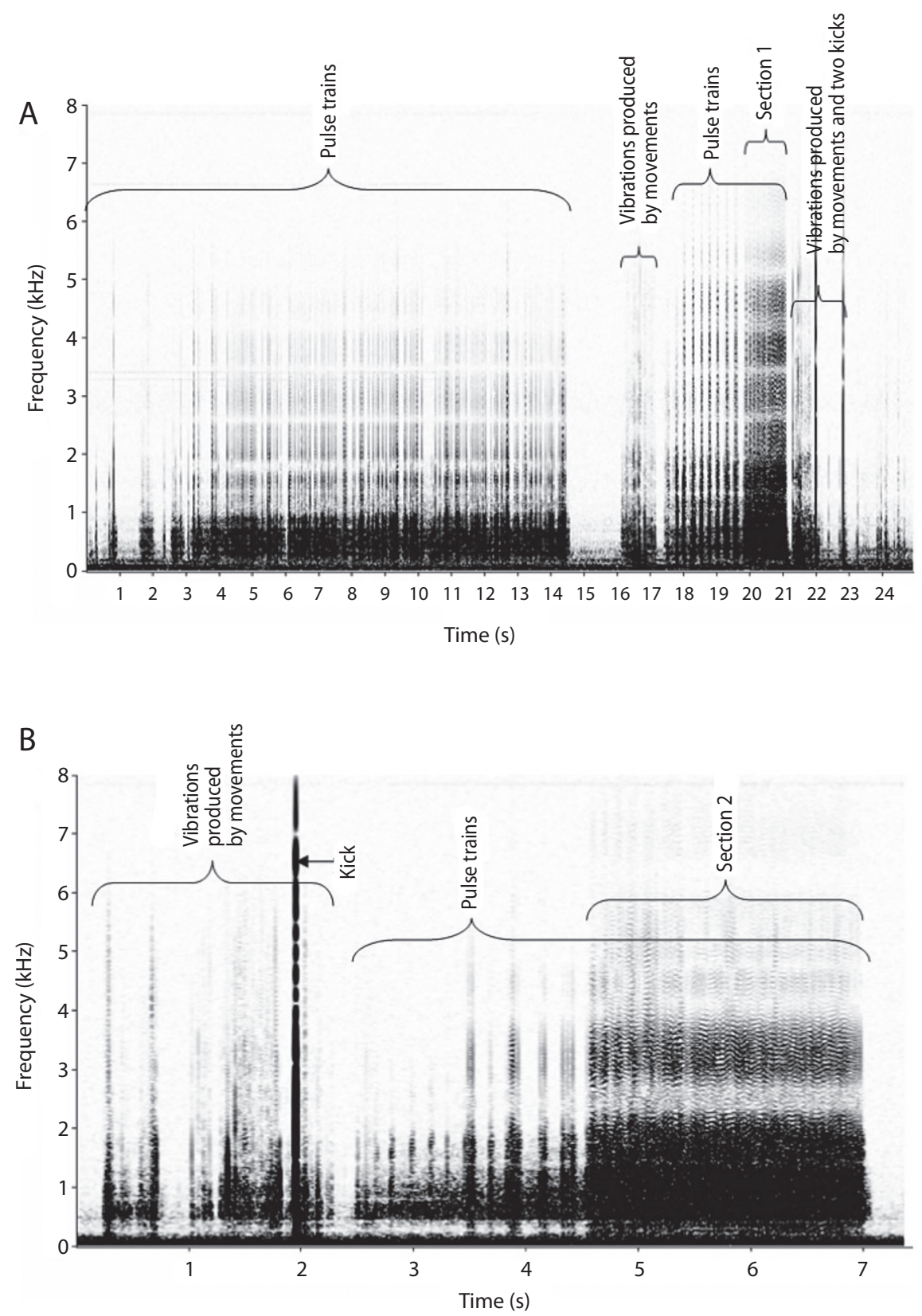

Fig. 4. Spectrogram of the disturbance signal of two different E. chrysura females (a-b). Note indicated pulse trains, vibrations produced by movements of the legs and body and sections with a high frequency of pulses per second (1-2). Sections 1 and 2 have 81.1 and 82.6 pulses per second, respectively. 


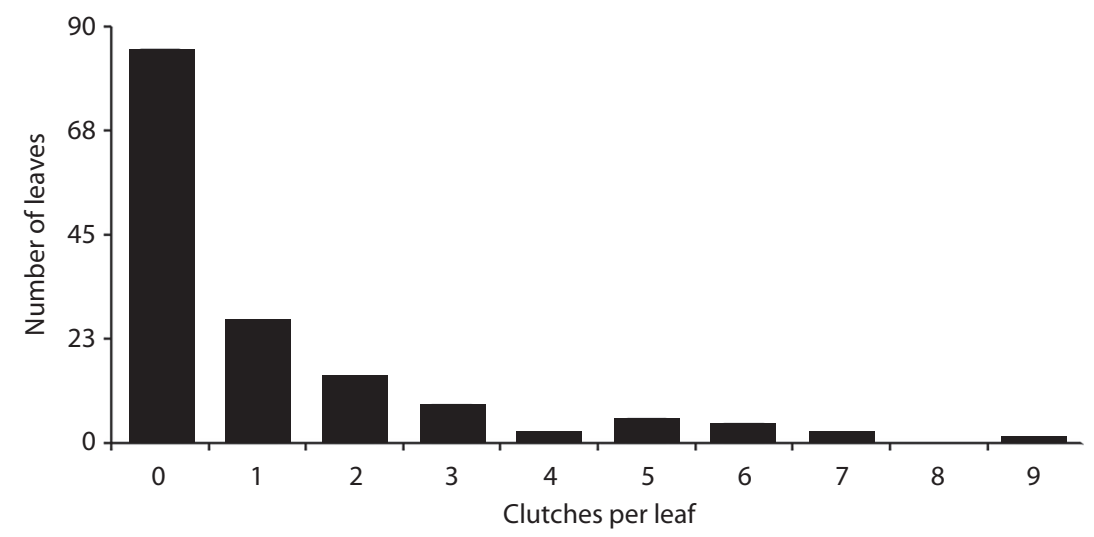

Fig. 5. Frequency distribution of E. chrysura egg clutches per leaf in the natural population. Escazú, Costa Rica.

TABLE 1

Spatial distribution pattern of Ennya chrysura egg clutches on each tree of the natural population

\begin{tabular}{ccccccc} 
Tree & Number of leaves & Average clutches/leaf & Variance clutches/leaf & Dispersion Index & $\mathrm{x}^{2}$ & P-value \\
1 & 25 & 0.2 & 0.2 & 1.4 & 33.5 & 0.094 \\
2 & 22 & 2.6 & 4.6 & $1.8^{*}$ & 37.5 & 0.014 \\
3 & 25 & 0.5 & 1.6 & $3.3^{*}$ & 79.7 & $<0.001$ \\
4 & 9 & 0.6 & 0.5 & 1.0 & 7.6 & 0.473 \\
5 & 23 & 1.8 & 5.5 & $3.1^{*}$ & 67.3 & $<0.001$ \\
6 & 15 & 0.7 & 2.5 & $3.8^{*}$ & 53.0 & $<0.001$ \\
7 & 28 & 1.1 & 2.7 & $2.5^{*}$ & 67.1 & $<0.001$ \\
\hline
\end{tabular}

*Indicates significant aggregation $(\mathrm{P}<0.05)$.

(2.26) both showed significant aggregation (chi square test: $\mathrm{x}^{2}=243.8$, d.f. $=65, \mathrm{P}<0.001 ; \mathrm{x}^{2}=$ 146.62, $\mathrm{P}<0.001$, respectively).

Sampled leaves were $23.7 \pm 6.8 \mathrm{~cm}$ long and $18.1 \pm 5.6 \mathrm{~cm}$ wide. Length and width were positively correlated $(\mathrm{r}=0.881, \mathrm{~N}=95$, $\mathrm{P}<0.001$ ), so only length was used as a leaf size indicator. Leaf size and number of egg masses were not correlated $(r=0.145, \mathrm{~N}=95$, $\mathrm{P}=0.162$ ). The proportion of leaves with at least one clutch was similar in all leaf size categories (Fig. 6A).

Females did not show a tendency to oviposit in leaves of certain age; leaves of all ages were occupied in similar proportions (log-likelihood ratio test: $g=0.043$, d.f. $=3, p=0.998$; Fig. 6B). Leaf age and number of clutches per leaf were not significantly correlated $(r=$
- 0.072, $\mathrm{N}=100, \mathrm{P}=0.476$ ), indicating egg masses did not just accumulate on old leaves.

Playback experiments: During the $3 \mathrm{~min}$ before experimental procedures, the proportion of females which moved slightly was similar in experimental and control females (Fig. 7a). One third of the females moved slightly during this period, but none kicked or vibrated. During the playback period, more experimental females moved slightly (Fig. 7b) and produced disturbance vibrations (Fig. 7d) than did control females. None of the females kicked at this moment. After the tactile stimulus, similar numbers of experimental and control females moved slightly (Fig. 7c), vibrated (Fig. 7d) and kicked (Fig. 7f).

Females which were experimentally exposed to the disturbance signal of another 

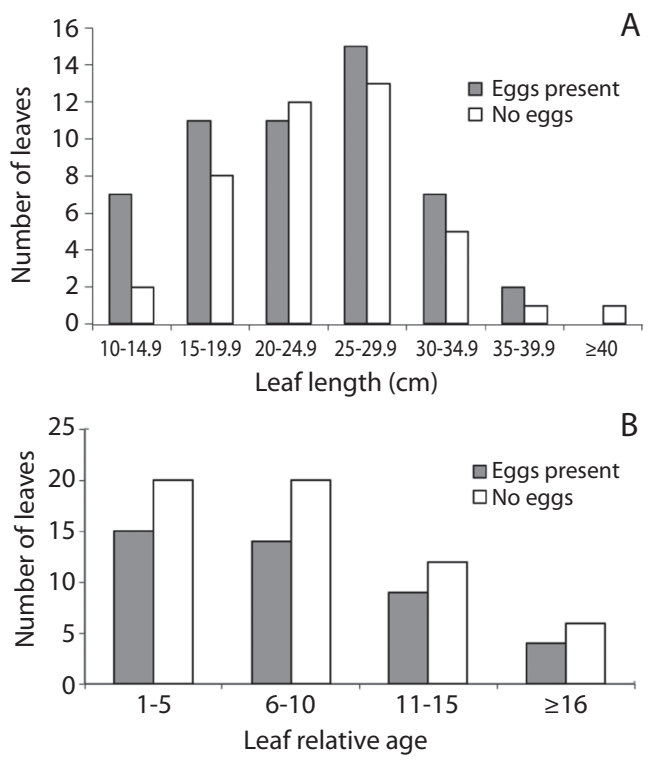

Fig. 6. A) Frequency distribution of E. chrysura egg clutches on leaves of different length $(\mathrm{cm})$. Proportion of occupied leaves was similar in all size categories (log-likelihood ratio test: $\mathrm{g}=4.39$, $\mathrm{df}=6, \mathrm{P}=0.62$ ). B) Frequency distribution of egg clutches on leaves of different ages (lower age numbers indicate younger leaves; log-likelihood ratio test: $\mathrm{g}=0.043$, $\mathrm{df}=3, \mathrm{P}=0.998$ ). Escazú, Costa Rica. female reacted more quickly to the tactile stimulus (Fig. 8); this difference was at the limit of significance in data of the first repetition (Wilcoxon test: $Z=1.50, \mathrm{~N}=18, \mathrm{P}=0.067 ; 1$ tail), and significant in the second repetition $(Z=1.96, \mathrm{~N}=13, \mathrm{P}=0.025 ; 1$ tail). The total reaction of experimental females was also higher during the playback and after the tactile stimulus, though significantly so in the second repetition only (Table 2). Before the playback, total reactions of control and experimental females were similar (Table 2). When the numbers of slight movements, vibrations, and kicks were analyzed separately, the treatment had an effect on slight movements and vibrations, but not on kicks (Table 2).

\section{DISCUSSION}

Laying and guarding eggs on a site where there are other egg-guarding females nearby are probably advantageous for females of $E$. chrysura. Aggregation did not seem to be due to a preference for leaves of a certain size or age, since there were both occupied and unoccupied leaves of all sizes and ages. Also,

TABLE 2

Quantified behaviors of experimental and control females before, during and after playback and contact (tactile stimulus), with their corresponding statistical tests

\begin{tabular}{|c|c|c|c|c|c|c|c|}
\hline Quantified Behaviors & $\begin{array}{c}\text { Experimental } \\
\text { Moment }\end{array}$ & Repetition & Experimental & Control & $\mathrm{Z}$ & $\mathrm{N}$ & $\mathrm{P}$ \\
\hline \multirow{6}{*}{$\begin{array}{l}\text { Total reaction } \\
\text { (sum of slight movements, } \\
\text { vibrations and kicks) }\end{array}$} & \multirow[t]{2}{*}{ Before playback } & 1 & $1.3 \pm 2.4$ & $2.3 \pm 5.7$ & 0.30 & 18 & 0.383 \\
\hline & & 2 & $0.1 \pm 0.3$ & $0.9 \pm 2.5$ & 1.34 & 13 & 0.090 \\
\hline & \multirow[t]{2}{*}{ During playback } & 1 & $1.7 \pm 3.4$ & $0.3 \pm 0.7$ & -1.42 & 18 & 0.078 \\
\hline & & $2^{*}$ & $1.9 \pm 2.2$ & $0.5 \pm 1.9$ & -1.78 & 13 & 0.038 \\
\hline & \multirow[t]{2}{*}{ After contact } & 1 & $4.1 \pm 5.6$ & $8.1 \pm 11.5$ & 1.45 & 18 & 0.074 \\
\hline & & $2^{*}$ & $9.3 \pm 8.8$ & $3.5 \pm 3.8$ & -1.76 & 13 & 0.038 \\
\hline \multirow[t]{4}{*}{ Number of slight movements } & \multirow[t]{2}{*}{ During playback } & 1 & $1.2 \pm 2.7$ & $0.3 \pm 0.7$ & -1.19 & 18 & 0.117 \\
\hline & & $2^{\mathrm{a}}$ & $1.8 \pm 2.1$ & $0.5 \pm 1.9$ & -1.61 & 13 & 0.053 \\
\hline & \multirow[t]{2}{*}{ After contact } & $1^{*}$ & $2.5 \pm 3.4$ & $6.5 \pm 10.3$ & 1.76 & 18 & 0.039 \\
\hline & & 2 & $6.3 \pm 7.4$ & $2.8 \pm 2.6$ & -1.20 & 13 & 0.115 \\
\hline \multirow[t]{4}{*}{ Number of vibrations } & \multirow[t]{2}{*}{ During playback } & $1^{*}$ & $0.4 \pm 1.0$ & 0 & -1.63 & 18 & 0.050 \\
\hline & & 2 & $0.2 \pm 0.6$ & 0 & -1.00 & 13 & 0.159 \\
\hline & \multirow[t]{2}{*}{ After contact } & 1 & $0.4 \pm 1.0$ & $<0.001$ & 0.00 & 18 & 0.500 \\
\hline & & $2^{*}$ & $0.2 \pm 0.6$ & $<0.001$ & -1.83 & 13 & 0.034 \\
\hline \multirow[t]{2}{*}{ Number of kicks } & \multirow[t]{2}{*}{ After contact } & 1 & $0.3 \pm 0.8$ & $0.3 \pm 0.8$ & 0.00 & 18 & 0.500 \\
\hline & & 2 & $0.8 \pm 1.5$ & $0.2 \pm 0.6$ & -1.29 & 13 & 0.099 \\
\hline
\end{tabular}

$\mathrm{Z}=$ Wilcoxon test, 1 tail. *Indicates significant difference with $\mathrm{P}<0.05$; letter ' $\mathrm{a}$ ' indicates nearly significant difference. 


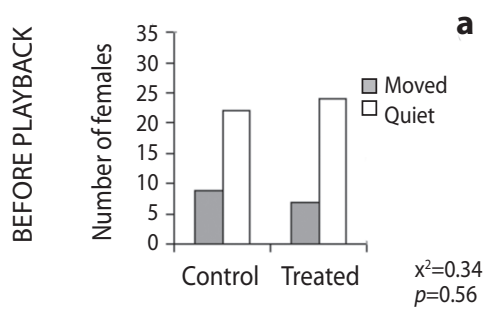

Absent

Absent
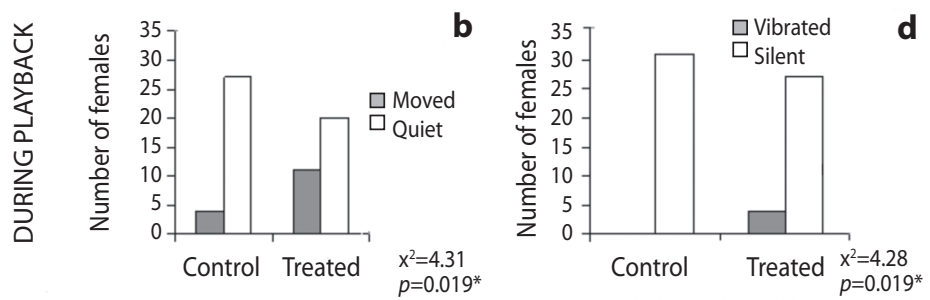

Absent
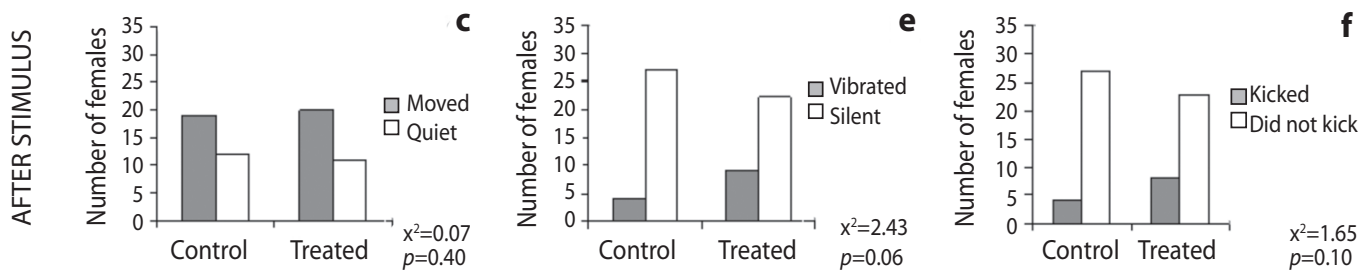

Fig. 7. Number of treated and control females of E. chrysura that moved slightly (a-c), vibrated (d-e), or kicked (f) before and during the playback, and after the tactile stimulus. Results of a chi square test for homogeneity $(\mathrm{df}=1)$ are shown for each figure; tests for $b-f$ are one tailed.

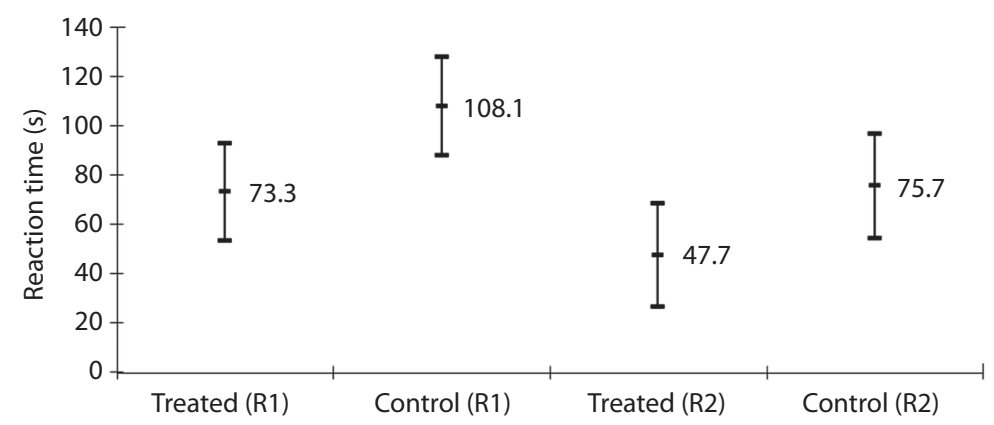

Fig. 8. Females of E. chrysura which were experimentally exposed to the disturbance signal of another female reacted more quickly to a tactile stimulus (average $\pm S E$ ); Wilcoxon one-tailed tests are of $Z=1.50, n=18, P=0.067$ in the first repetition (R1), and $\mathrm{Z}=1.96, \mathrm{n}=13, \mathrm{P}=0.025$ in the second repetition ( $\mathrm{R} 2$ ).

aggregation did not seem to be the result of gradual accumulation of clutches on particular leaves, since new clutches showed an aggregated pattern irrespective of old clutches.

These data also suggest that guarding behavior was associated with lower egg parasitism. Cause and effect cannot be confirmed, however, as it is also possible that females had abandoned egg masses after more intense attacks by parasitoids or that they spontaneously abandoned some clutches which were subsequently more heavily parasitized. 
The signal produced by egg-guarding females when disturbed was similar to a disturbance signal named drumming in a previous study (Miranda, 2006) described as pulse trains with no harmonic structure and of variable duration (a mean of $1.7 \pm 0.9 \mathrm{~s}$ ) and separated by silence intervals of variable length (a mean of $0.71 .1 \mathrm{~s}$ ). Drumming was observed in nonguarding females, when a conspecific contacted them, or when they rejected a courting male (Miranda, 2006). Disturbance calls, kicking and wing vibrating had been reported when $E$. Chrysura guarded eggs from parasitoid wasps (Godoy et al., 2006). Presumably, drumming functions to warn off a disturbing animal, as it has been sugested for vibrations produced by other treehoppers in similar contexts (Masters, 1979; Buchler et al., 1981; Klump \& Shalter, 1984; Cocroft \& Hamel, 2010), but this has not been tested. Segments with a higher pulse rate than previously described by Miranda (2006) were observed only after stimulating females with the brush several times and may indicate a higher disturbance level. The disturbance signal produced by the treehopper Publilia concava, also consists of pulse trains of a similar, wide frequency range $(0-7 \mathrm{kHz})$; tending ants respond to this signal in $P$. concava (Morales et al., 2008), but since E. chrysura is not tended by ants (Godoy et al., 2006) this additional function is not expected.

The experiments of the present study demonstrated that disturbance vibrations are probably utilized by nearby females as an alarm signal. Females that were experimentally exposed to the disturbance signal of another female reacted more quickly to the tactile stimulus with defensive behavior and also vibrated more than control females. Some of them even reacted to the signal alone, before the tactile stimulus. In nature, a quicker, longer and sustained response to the first attack of a predator or parasitoid is probably advantageous, especially when considering the sum of several different potentially intimidating and/ or deterring behaviors, including disturbance signals. Kicks are often effective aggainst small parasitoid wasps (Miranda, unpublished data); females only kicked after the tactile stimulus, which means that besides the alarm signal from other females, they probably still rely on other tactile, visual and olfactory cues from enemies or conspecifics to regulate their defensive response. The possibility of a substrate-borne distress signal that may put other egg-guarding females on alert and increase their irritability was previously discussed for another treehopper, Alchisme grossa (Camacho et al., 2014) but this is the first experimental study that supports this idea in the Membracidae. The degree of kinship between females on a plant is not known. If females on the same plant are genetically related, as in some other treehopper species (Eberhard, 1986; Wood, 1993), it is possible that the disturbance vibrations that females produced have also been favored by kin selection to improve egg defense by nearby females (Wong et al., 2013).

Future research may be able to overcome some of the limitations of the present study. The changes imposed by the playback system could be measured in future experiments in order to compensate for them by pre-filtering the playback signal; using recordings of several different females is also advisable (Cocroft, Hamel, Su, \& Gimson, 2014). Nevertheless, the same equipment that was used in this study has also been used to produce playbacks of male calls; since females have responded with their dueting signal (unpublished data) we know that this equipment is capable of reproducing the signals faithfully enough to be recognized by receivers. The disturbance signal is made of pulses of such a wide range of frequencies, that the temporal pattern was kept for most of the frequencies, even after the filtering of different plants. Since intensity of the playbacks was carefully calibrated, there is no reason to believe that the results of these experiments would be significantly affected by the playback system. Another possible methodological refinement would be to control temperature and examine variables for temperature-related variation; pulse rate and frequency could be adjusted by using the slope of the regression of the signal trait on temperature if necessary 
(Cocroft, Rodríguez, \& Hunt, 2010). However, although the present study did not control temperature, it did include an experimental design with alternation of experimental and control procedures partly to avoid possible temperature biases in the females' levels of activity. The possibility that the disturbance signal results in communication between eggguarding females, supported by the present paper, is worth exploring further since it suggests cooperative care in female treehoppers mediated by vibrational communication.

\section{ACKNOWLEDGMENTS}

I thank William Eberhard, Paul Hanson, Daniel Briceño and Rafael L. Rodríguez for advice and revisions of the manuscript. Reginald Cocroft (University of Missouri, Columbia) donated the substrate-borne recording equipment. John Huber (Canadian National Collection) helped with wasp identification. Alicia Escobar patiently stimulated females with the brush in playback experiments. Werner Bansbach assisted in field work and image preparation. Lydia Garnier and Mario Miranda helped with equipment and space for the laboratory and colony. Photographs are from Kenji Nishida. I give my sincere thanks to all of them. All experiments comply with the laws of Costa Rica.

\section{RESUMEN}

Después de un estudio más general sobre la historia natural y la comunicación por vibraciones de sustrato del membrácido Ennya chrysura, este artículo explora con mayor profundidad los comportamientos específicamente relacionados con el cuido de los huevos. En condiciones naturales (San Antonio de Escazú, Costa Rica), las hembras de E. chrysura con frecuencia protegen sus masas de huevos, y el cuido está asociado con un menor porcentaje de parasitismo causado por las avispas parasitoides de huevos Gonatocerus anomocerus and Schizophragma sp. (Mymaridae). Las hembras tendían a poner sus huevos en la cercanía de otras hembras con huevos, y producían vibraciones de sustrato en respuesta a disturbios. Se confirmó un patrón agregado bajo condiciones naturales, calculando índices de dispersión a partir del número de masas de huevos en 66 hojas. La señal fue descrita a partir de grabaciones hechas en el laboratorio con 10 hembras que protegían sus huevos. Los experimentos conducidos con 18 hembras mostraron que aquellas que fueron expuestas a la señal de disturbio de otra hembra, se movieron ligaramente o vibraron más durante el experimento, y reaccionaron a un estímulo táctil más rápidamente y con un mayor número de comportamientos defensivos. Las señales producidas durante la defensa de huevos podrían entonces funcionar como alarma, y favorecer la agrupación con otras hembras que también protegen sus huevos.

Palabras clave: señales de alarma, vibraciones de sustrato, comunicación de membrácidos, cuido parental, comportamiento de insectos.

\section{REFERENCES}

Avisoft Bioacoustics. (2002). Hardware and Software for Investigating Animal Acoustic Communication. Berlin: Avisoft-SASLab Pro Sound Analysis and Synthesis Software. Retrieved from http://www.avisoft.com/ soundanalysis.htm

Blumstein, D. T., Evans, C. S., \& Daniel, J. C. (2000). Jwatcher 0.9 An Introductory User's Guide. Australia: Animal Behaviour Laboratory, Macquarie University.

Buchler, E. R., Wright, T. B., \& Brown, E. D. (1981). On the functions of stridulation by the passalid beetle Odontotaenius disjunctus (Coleoptera: Passalidae). Animal Behaviour, 29, 483-486.

Camacho, L., Keil, C., \& Dangles, O. (2014). Factors influencing egg parasitism in sub-social insects: insights from the treehopper Alchisme grossa (Hemiptera, Auchenorrhyncha, Membracidae). Ecological Entomology, 39, 58-65.

Claridge, M. F. (1985). Acoustic signals in the Homoptera: behavior, taxonomy, and evolution. Annual Review of Entomology, 30, 297-317.

Cocroft, R. B. (2003). The social environment of an aggregating, ant-attended treehopper (Hemiptera: Membracidae: Vanduzea arquata). Journal of Insect Behavior, 16, 79-95.

Cocroft, R. B., \& Rodríguez, R. L. (2005). The behavioral ecology of insect vibrational communication. Bioscience, 55, 323-334.

Cocroft, R. B., \& McNett, G. D. (2006). Vibratory Communication in Treehoppers (Hemiptera: Membracidae). In S. Drosopoulos \& M. F. Claridge (Eds.), Insect Sounds and Communication: Physiology, Behaviour, Ecology and Evolution (pp. 305-317). London: CRC Press.

Cocroft, R. B., \& Hamel, J. A. (2010). Vibrational communication in the "other insect societies": A diversity of ecology, signals, and signal functions. In C. 
O'Connel-Rodwell (Ed.), The use of vibrations in communication: properties, mechanisms and function across taxa (pp. 7-41). India: Research Signpost.

Cocroft, R. B., Rodríguez, R. L., \& Hunt, R. E. (2010). Host shifts and signal divergence: mating signals covary with host use in a complex of specilized plantfeeding insects. Biological Journal of the Linnean Society, 99, 60-72.

Cocroft, R. B., Hamel, J. A., Su, Q., \& Gimson, J. (2014). Vibrational Playback Experiments: Challenges and Solutions. In R. B. Cocroft, M. Gogala, P. S. M. Hill, \& A. Wessel (Eds.), Studying Vibrational Communication (pp. 248-274). Berlin: Springer-Verlag.

Eberhard, W. G. (1986). Possible mutualism between females of the subsocial membracid Polyglypta dispar (Homoptera). Behavioral Ecology and Sociobiology, $19,447-453$.

Godoy, C., Miranda, X., \& Nishida, K. (2006). Treehoppers of tropical America. Costa Rica: National Institute of Biodiversity.

Klump, G. M., \& Shalter, M. D. (1984). Acoustic behavior of birds and mammals in the predator context: I. Factors affecting the structure of alarm signals, II. The functional significance and evolution of alarm signals. Zeitschrift fur Tierpsychologie, 66, 189-226.

Krebs, C. J. (1999). Ecological Methodology. California: Addison-Wesley Educational Publishers Inc.

Lin, C. P. (2006). Social behaviour and life history of membracine treehoppers. Journal of Natural History, 40, 1887-1907.

Marshall, D. C. (2000). Behavior and evolution of periodical cicadas (Magicicada spp.) (Ph.D. dissertation). University of Michigan, Michigan, USA.
Masters, W. M. (1979). Insect disturbance stridulation: its defensive role. Behavioral Ecology and Sociobiology, $5,187-200$

Miranda, X. (2006). Substrate-borne signal repertoire and courtship jamming by adults of Ennya chrysura (Hemiptera: Membracidae). Annals of the Entomological Society of America, 99, 374-386.

Morales, M. A., Barone, J. L., \& Henry, C. S. (2008). Acoustic alarm signalling facilitates predator protection of treehoppers by mutualist ant bodyguards. Proceedings of the Royal Society, 275, 1935-1941.

Stegmann, U. E., \& Linsenmair, K. E. (2002). Subsocial and aggregating behaviour in Southeast Asian treehoppers (Homoptera: Membracidae: Centrotinae). European Journal of Entomology, 99, 29-34.

Syntrillium Software Corporation. (1999). Cool Edit Pro Version 1.2 User Guide Addendum. Syntrillium Software Corporation. Retrieved from http://www.inventati.org/akusmatik/base/tutorials/manual/cep12add.pdf

Wong, J. W. Y., Meunier, J., \& Kölliker, M. (2013). The evolution of parental care in insects: the roles of ecology, life history and the social environment. Ecological Entomology, 38, 123-137.

Wood, T. K. (1984). Life history patterns of tropical membracids (Homoptera: Membracidae). Sociobiology, 8, 299-344.

Wood, T. K. (1993). Diversity in the New World Membracidae. Annual Review of Entomology, 38, 409-35.

Zar, J. H. (1996). Biostatistical Analysis (3rd ed). New Jersey: Prentice-Hall. 